\title{
Colon Small Cell Carcinoma
}

National Cancer Institute

\section{Source}

National Cancer Institute. Colon Small Cell Carcinoma. NCI Thesaurus. Code C6761.

An aggressive, high-grade, and poorly differentiated carcinoma with neuroendocrine differentiation that arises from the colon. It is characterized by the presence of malignant small cells. 